\title{
Kashmir Conflict: Alarming Mental Health Consequences
}

\author{
Nuzhat Firdous ${ }^{1}$
}

\section{ABSTRACT}

War damages the very fabric of the society. It not only damages its physical structure but also disrupts its entire social tissue, its environment and the normal routine of life for which people account several reasons. Kashmir has been witnessing a chronic socio-political unrest for the last $2 \frac{1}{2}$ decades now. The conflict has had an enormous impact on different aspects of Kashmir's society. Indeed, there has been a colossal damage to the property and infrastructure; however, its impact can be felt nowhere more than on the mental health of the people of Kashmir. Deliberating upon the human suffering, the conflict has not only left thousands dead and orphaned, unleashed and unmitigated violence on women and children, but the alarming increase in the psychiatric morbidity in general, is among the worst possible forms of suffering. This paper thus attempts to give an up-to-date description of the current mental health scenario and ensuing physiological and behavioural implications among the people of Kashmir. Database for this review included PubMed, medIND, Google scholar, and a number of reputed dailies. The studies reviewed have been published in peer reviewed journals, featuring the socio-political chaos in kashmir and its overall effect on the fate-bitten residents.

Keywords: Kashmir Conflict, Violence, Mental Health, Physiological \& Behavioural Manifestations.

The prolonged, conflict has taken a heavy toll on the people of Kashmir, destabilising their economic, social and political lives. The emotional and psychological impact of the resulting violence is deeply felt by all, irrespective of gender, age, occupation and location. The uncertainty of life is usually summed up in a common utterance that once people leave home, they are not certain if they would return again.

Studies conducted so far clearly indicate that exposure to violence has latent implications for mental health. In areas affected by chronic strife a larger chunk of population is expected to experience mental health problems and such figures ought to apply to the people of Kashmir where high levels of psychological distress has been seen prevalent in the (Jong, Kam, Ford, Lokuge, Fromm, Galen, et al. 2008). A considerable increase in the number of people being diagnosed with acute stress reaction, depressive disorders, anxiety disorders, and post traumatic stress disorder (Khan \& Beg, 1993; Margoob, Firdosi, Banal, Khan, Malik, Sheikh, et al. 2006)

\footnotetext{
${ }^{1}$ Ph.D. from Department of Psychology, Jamia Millia Islamia, New Delhi and is Currently working as Lecturer, Govt. Degree College, Ganderbal, Kashmir, Jammu \& Kashmir

(c) 2015 I N Firdous; licensee IJIP. This is an Open Access Research distributed under the terms of the Creative Commons Attribution License (http://creativecommons.org/licenses/by/2.0), which permits unrestricted use, distribution, and reproduction in any Medium, provided the original work is properly cited.
} 


\section{Kashmir Conflict: Alarming Mental Health Consequences}

where the prevalence of post traumatic stress disorder is reported to be 15.9\% (Margoob \& Sheikh, 2006) which is quite alarming for the state when compared to other places.

Mental disorders in Kashmir have increased drastically since 1980s. A yearly average of 1200 to 1400 patients, were seeking treatment during 1980s. Study conducted by Margoob, the valleys leading psychiatrist, reveals that about 1700 patients had visited Kashmir's sole psychiatric department in the year 1990, but in year 2002 the number had gone up to 48,000 and by December 2004, a total of 62,000 patients had visited the psychiatric services of the department (Margoob, 1995).According to a survey conducted by State Mental Health Society (SMHS), around 80,000 people from Kashmir valley have visited various mental health professionals during the 2005-06 and nearly three fourth have been diagnosed with serious psychological disorders. The records from the outpatient department (OPD), of government psychiatric disease hospital Srinagar show that more than 300 people visit for consultation every day (Hashmi, 2007). The facts are also corroborated by Saiba Verma, a researcher at the department of Anthropology, Cornell University, who reports that, "the Srinagar Psychiatric hospital had about 1,700 visitors in 1990 , and the number grew to over 100,000 in 2007 . The figure only represents the tip of the ice-berg as many people do not visit mental health experts because of the huge stigma attached to it”, she adds (Verma, 2009).

Study conducted by MSF (doctors without borders), a non-governmental organisation, has found an alarming increase in the suicide rates by 400 times because of the ongoing violence (Bukhari, 2010). Moreover, the State hospital has recorded a number of 100 cases in May 2007, which included cases of deliberate self-harm, serious attempts at suicide, and complete suicides. Out of these 100 cases, 83 were women and only 17 were men. Since women live in the state of bereavement, majority of female patients suffer from Major Depressive Disorders, almost 50\% have Post Traumatic Stress Disorder. Experts believe that the sudden assumption of male responsibilities, psychological trauma of both reported and unreported sexual violence and the overall stressful environment may be largely contributing to the worsening mental health amongst women. The very same hospital has also registered 50 cases of suicide attempts till June 13 including 15 cases in the first four days of June (Zia, 2007).Most of the people who complete suicide are young males in the age group 25-34. (Hussain, 2008). A survey done in four districts of the region found that one third of the respondents contemplate suicide (Jong, et al. 2008).

In addition to this, a substantial increase in the use of sedatives and drugs has been seen in the masses. Studies comparing the prevalence of substance misuse pre and post conflict reveals that the use of substances is ever increasing whereby use of alcohol has increased by $30 \%$ in a society where alcohol use was almost nonexistent. Use of uploads has increased from $9 \%$ to $73 \%$, people using multiple substances has increased from $15 \%$ to $41 \%$. The same study concluded that $15 \%$ of people attributed their drug use to the prevailing trauma and turmoil (Margoob, 2004)."People cope with the trauma and negative emotional states by using anything, many substances to 


\section{Kashmir Conflict: Alarming Mental Health Consequences}

induce a temporary state of sleep and rest" writes Murali Krishnan quoting Mushtaq Margoob, the leading psychiatrist of the valley (Krishnan, 2010).

A more recent study revealed the prevalence rate of depression to be (55.72\%) where depression has been seen more prevalent (66.67\%) in the 15 to 25 years age group, followed by (65.33\%) in the 26 to 35 years age group. Moreover, a high percentage of depressive disorder has been found in rural areas (84.73\%) as compared to urban areas $(15.26 \%)$. Moreover, the prevalence of depression among females has been seen higher (93.10\%)as compared to males (6.8\%) in rural areas (Amin \& Khan, 2009).

The worst part of the conflict is that it equally affected the psyche of children which are considered to be the future of a given society. Study conducted by Khan and Margoob found that most common traumatic event experienced by children was witnessing the killing of a close relative (49\%), followed by witnessing the arrest and torture of a close relative (15\%) (Khan \& Margoob, 2006). Parental loss, frequent displacement and exposure to violence have led to an increase in paediatric psychopathology. Since children lack the cognitive capacities than the adults and find it difficult to talk upon their traumatic experiences. Unable to transform their internal conflicts and feelings into words, they are expressed in repetitive re-enactments, intrusive visual images, trauma specific fears, aggressive and regressive activities, and other behaviouralstates. Behavioural changes amongst children and youth is seen in the form of isolation, aggression (including stone-pelting), drug abuse, lack of respect for elders, loss of morality/values and hopelessness. Such emotional and behavioural reactions has also been seen in Palestinian children which are manifested in a number of ways including problems with speech, difficulty concentrating, learning difficulties, sleep related problems, bedwetting, loss of recently acquired skills, feelings of guilt, and variety of somatic complaints (Mousa, 2009). It has been noticed that older children are more vulnerable than younger children to the psychological effects of war (Bloch, Silber, \& Perry, 1956).

Owing to parental loss, most of the children are often reared in orphanages and PTSD and depression are seen common diagnoses in children living in orphanages (Margoob, 2006) (Margoob, Rather, Khan, Singh, Malik, Firdosi, et al. 2006). Study conducted by Margoob et al (2006) also found a greater vulnerability of psychiatric morbidity in female children of 5-12 years of age range.

The younger child's psychological response resonates with the parental response as they have less cognitive capacity to independently evaluate the dangers. Vizek-Vidovi et al. (2000) compared younger children (grades 2-5) with an older group (grades 6-8) in Croatia, and found that the older children manifested more depressive and anxiety reactions. Children who are in general not exposed to war, i.e if they are not born in war-like conditions, they find it more difficult to cope up in war-like situations and exhibit Post Traumatic Stress Disorder for very long periods of time. While the ones born in war-torn areas grow mentally tough and aggressive. 


\section{Kashmir Conflict: Alarming Mental Health Consequences}

Dar (2012), while assessing the needs of youth in Kashmir maintains that the youth of Kashmir have bore the major brunt of the ongoing violence, not only by making up the majority of dead and missing but also of arrests, beatings, detentions, rapes and other forms of everyday harassment.

Owing to deaths and disappearances of male members, many women have no choice but to head their families and bear the responsibility. The most precarious position of "half widows" or women, unsure of the fate of their husbands, is even more distressing. These women neither can inherit property or claim widow benefits nor they can remarry as according to Islamic law they must wait for at least seven years (Manecksha, 2011).This sense of insecurity has given rise to several psycho-physiological pathologies. The constant stress experienced by the women folk has adversely affected their reproductive health as well, resulting in frequent miscarriages, polycystic ovarian disease (PCOS), premature ovarian failure (POF-commonly called menopause) which is alarmingly high (20-50\%) when compared to India's national POF rate of 1-5 percent (Yosuf, 2014).

The extensive reports by local, national and international human rights organisations have been highlighting the issue consistently. One such report is given by a human rights organisationHuman Rights Watch. The report reads:

"Suspicion and fear continue to permeate the Kashmir valley. A knock on the door late at night send spasms of anxiety through households, afraid that a family member will be asked by the security forces or militants to step outside for "a minute" and then never return. Psychological trauma related to the violence has been enormous, as life itself is constantly under threat" (Human Rights Watch, 2006).

The report and others like it have drawn national and international attention towards "an epidemic of trauma" in the Kashmir valley, which has, in turn, led to a range of institutional responses, from formal to informal, from both state and non-state actors. In other words, mental health has emerged as one of the most pressing public health concerns in contemporary Kashmir. The long standing dispute has caused Post Traumatic Stress Disorder (PTSD) among up to 90\% people of the valley, which makes around six million populations. Justine Hardy, a British author and journalist, while witnessing the impact of the protracted conflict on the mental health of people for the last 20 years maintains, "The conflict had a great cost in terms of mental health of the people of the occupied territory. The conflict has caused long term mental damage among a high percentage of the population. The shock after seeing their children being blown up, bodies of their beloved ones delivered to their doorstep and witnessing the unrecognizable bodies of the relatives resulted in nervous breakdown among the people. It reduced the individual to a barely functioning state.” 


\section{CONCLUSION}

Since the mental health services took birth from the erstwhile mental asylum, there is a stigma attached in being a psychiatric patient, which is also true to other places. The studies also reveal that more than $80 \%$ people with mental health problems face stigma as one of the main barriers to recovery (Pande, 2009).

The concept of mental health in Kashmir can best be described as orthodox. The mental health services continue to remain segregated instead of getting integrated into the overall health care system, confined to Govt. Psychiatric Disease Hospital, Srinagar as the main centre to cater to the needs of the whole valley-a population of about eight million, with no psychiatric centers nor any extension of services to other parts of the valley even in the present stressful circumstances. Hence, Government needs to pay attention to the existing psychiatric centers, make certain advancements in these centers to ensure their infrastructure, staff, equipment and other facilities. Efforts need to be made to ensure community participation in the after care and rehabilitation of mentally disordered patients. Since hospitalisation and pharmacological treatment is not sufficed to ensure the success of any form of mental health service.

Mental health literacy is an equally important issue. Firstly awareness generating campaigns are required whereby public could be educated about what mental disorders actually mean. Mental health literacy should be given the same priority as for cancer, AIDS etc, via electronic and mass media.

Finally to cope with the prevailing situation in Kashmir and its effects on the mental health of the average person, a network of trained counsellors is the need of the hour. Counselling centres/counsellors can be helpful to the victims of torture and those suffering from trauma related mental problems. If the prevailing environment cannot be changed, we can at least design our mental sets in such a manner that could result in healthier mental status, calling an attention from scholars and policymakers alike.

\section{REFERENCES}

Amin. S., \& Khan, A. W. (2009). Life in Conflict: Characteristics of Depression in Kashmir. International Journal of Health Sciences, 3(2), 213-223. Retrieved from http://www.ncbi.nlm.nih.gov/pmc/articles/PMC3068807/

Bloch, D. A., Silber, E., \& Perry, S. E. (1956). Some factors in the environmental reactions of children of disaster. The American Journal of Psychiatry, 150, 235-239.

Bukhari, P. (May 22, 2010). Why the valley blooms. Tehelka Magazine. Retrieved from http://www.tehelka.com.

Dar, F. A. (2012). 'Living in a pressure cooker situation' A needs assessment of youth in Indianadministered Kashmir. Conciliation Resources. Retrieved from: www.m.cr.org/node/1993. 


\section{Kashmir Conflict: Alarming Mental Health Consequences}

Hashmi, S. J. (2007). Trauma of Daily Violence in Jammu \& Kashmir, Telling Upon Mental Health. Retrieved on Sept, 21, 2012. Retrieved from http://www.countercurrents.org

Human Rights Watch (2006). Everyone lives in Fear: Patterns of impunity in Jammu and Kashmir, 18(11). Retrieved from http://www.hrw.org/sites/default/files/reports/india0906web.pdf

Hussain, A. (2008). Muslim Suicide-Kashmir experience. European Psychiatry, 23, S84.

Inter-Agency Standing Committee (2007). IASC Guidelines on Mental Health and Psychosocial Support in Emergency Settings. Geneva. Retrieved from http://www.humanitarianinfo.org/iasc

Jong, K. D., Kam, S. V. D., Ford, N., Lokuge, K., Fromm, S., Galen, R. V., et al. (2008). Conflict in the Indian Kashmir Valley II- psychosocial impact. Conflict and Health, 2, 11.

Khan, A. W.,\& Beg, A. A. (1993). A study of psychiatric morbidity in Kashmir under stressful conditions in the valley. MD Thesis, (Unpublished).

Khan, A. Y., Margoob, M. A. (2006). Pediatric PTSD-Clinical Presentation, Traumatic Events and Socio-demographic Variables-Experience from a Chronic Conflict Situation. JK Practitioner, 13, S40-4.

Krishnan, M. (2010). Conflict in Kashmir valley takes its toll on mental health. Deutsche Welle. Retrieved October 12, 2012, from Jamia Millia Islamia, Department of Psychology.

Manecksha, F. (2011). Traumatised by Violence. Violence and Health. Available From: http://indiatogether.org/kashmir-health

Margoob, M. A. \& Sheikh, A. A. (2006). Community prevalence of adult PTSD in South Asiaexperience from Kashmir. JK-Practitioner, 13, 18-25.

Margoob, M. A. (1995). A study of present magnitude of psychiatric disorders and the existing treatment services in Kashmir(1990-1994). JK- Practitioner, 2(3), 165-168.

Margoob, M. A., Firdosi M. M., Banal, R., Khan, A. Y., Malik, Y. A., Sheikh, A. A., et al. (2006). Community Prevalence of Trauma in South Asia-Experience from Kashmir. JKPractitioner, 13, 14-17.

Margoob, M. A., Majid, A., Hussain, A., Wani, Z. A., Yousf, A., Malik, Y. A., et al. (2004). Changing socio-demographic and clinical profile of substance use disorder patients in Kashmir valley. JK- Practitioner, 11, 14-16.

Margoob, M. A., Rather, Y. H., Khan, A. Y., Singh, G. P., Malik, Y. A., Firdosi, M. M., et al. (2006). Psychiatric Disorders among Children living in Orphanages- Experience from Kashmir. JK- Practitioner, 13, S53-5 .

Mousa, Y. (2009). The Psychological effects of War on Gaza's children. Retrieved from:

Pande A. Mental health related stigma reduces access to existing services.CNS articles 2009.

Verma, S. (2009). Healing Kashmir? Psychiatry in Practice. Kashmir Times.

Vizek-Vidovi, V., Kuterovac-jagodic, G., \& Arambasic, L. (2000). Posttraumatic symptomatology in children exposed to war. Scand J Psychol; 41(4): 297-306.

www. Labournet.net/world/0920/uhwc1.html.

Yousuf, S. (2014). Depression casts cloak of infertility over Kashmir valley. Inter press service.

Available From: http://www.ipsnews.net/2014/11/depression-casts-cloak-ofinfertility-over- kashmir-valley/

Zia, A. (2007). Kashmiri Women: Concerns, Milestones \& Solutions. Kashmir Affairs. Retrieved from http://www.kashmiraffairs.org/Zia_Ather_Kashmiri_women.html 